\title{
Acral vascular necrosis associated with immune-check point inhibitors: case report with literature review
}

\author{
Karam Khaddour ${ }^{* *}$, Veerpal Singh ${ }^{2}$ and Maryna Shayuk ${ }^{1}$
}

\begin{abstract}
Background: Treatment of solid malignancies has been revolutionized with the introduction of immune checkpoint inhibitors (ICls) and their use is being expanded in therapy of different cancers. However, immune related adverse events (IRAEs) can occur during treatment. These side effects occur due to stimulation of the innate and adaptive immune system and can lead to serious complications. Recently, acral ischemia has been reported in some cases during treatment with programmed death-1 (PD-1) and cytotoxic T lymphocyte associated antigen-4 (CTLA-4) inhibitors. Here, we discuss a case in which acral necrosis developed after initiation of a PD-1 inhibitor. We offer a review of the existing literature on the pathophysiology, clinical course and treatment outcomes.

Case presentation: A 68-year-old female was diagnosed with stage IV non-small cell lung adenocarcinoma and was started on pembrolizumab. The patient developed sudden onset numbness and discoloration of fingertips bilaterally at week 25 after initiation of $\mathrm{ICI}$ treatment. Extensive workup to rule out hypercoagulable, autoimmune and vascular disease was unremarkable except for mild elevation of ANA and ESR. The symptoms quickly progressed into dry gangrene within four weeks and did not respond to medical or surgical treatment. Pembrolizumab was subsequently discontinued due to progression of metastatic disease. The patient refused further interventions and transitioned to hospice care where she expired after two months.

Conclusion: Acral ischemia can develop during treatment of malignancies. This complication, although uncommon, canresult in digital amputation. Physicians should be aware of the possible progression of acral vascular necrosis when Raynaud's like symptoms develop. Larger studies are needed to confirm the role of ICls in the pathogenesis of acral vascular necrosis.
\end{abstract}

Keywords: Acral ischemia, Necrosis, Case reports, Small vessel vasculitis, Immunotherapy, Immune related adverse events (IRAEs)

\section{Background}

In May 2017, BMC Cancer Journal published a case report by Gambichler et al. describing development of paraneoplastic acral vascular necrosis in association with CTLA-4 and PD-1 inhibitors during treatment of metastatic melanoma [1]. Other reports described similar findings under different diagnostic terms including small vessel vasculitis and digital ischemia. This newly observed adverse event although not reported in phase I/II trials appears to be significant should necrosis progresses requiring surgical

\footnotetext{
* Correspondence: Karam.khaddour@gmail.com

${ }^{1}$ Rosalind Franklin University of Medicine and Science, 915 Armistead Lane,

McHenry, Chicago, IL 60050, USA

Full list of author information is available at the end of the article
}

amputation. Immune checkpoint inhibitors (ICIs) enhance the immune system through blockage of costimulatory signal receptors that are present on normal and cancer cells, which facilitate tumor evasion by inducing tolerance and anergy. The resultant adverse events of hyperstimulation of the immune system during treatment with ICIs are termed immune related adverse events (IRAEs). These side effects can have a wide spectrum of manifestations such as acute hypophysitits, colitis, pneumonitis and rarely myocarditis. Moreover, vasculitis has been described to occur during treatment mostly in large and medium size vessels. Recently, some reports suggested an association between ICIs and small vessel vasculitis, which might lead to digital ischemia and necrosis. 


\section{Case presentation}

A 68-year-old Caucasian female presented to our hospital with shortness of breath and unintentional weight loss of 30 pounds three months prior. The patient was an active smoker and her past medical history included well controlled type 2 diabetes mellitus (Hemoglobin A1C 6.0\%) and non-obstructive coronary artery disease. Her medication included insulin, aspirin and metoprolol succinate. Thoracic computed tomography showed an interlobular mass in the medial right upper lobe with extension into the right hilum (Fig. 1). Tissue biopsy was performed and histopathology was consistent with non-small cell adenocarcinoma with negative EGFR mutation, ALK and ROS-1. Programmed Death Ligand-1 (PD-L1) expression by immunohistochemistry was $70 \%$. The clinical staging with Positron Emission Tomography- Computed Tomography (PET-CT) scan showed mediastinal metastatic lymph nodes and scattered osseous metastases in the axial and proximal appendicular skeleton (Stage IV; T4, N3, M1b). Given the high expression of PD-L1 $>50 \%$, immunotherapy with pembrolizumab was started at $(200 \mathrm{mg})$ intravenously once every three weeks per KEYNOTE-024 protocol [2]. Subsequent surveillance with $\mathrm{CT}$ showed a significant decrease in the size of the primary tumor in the lungs

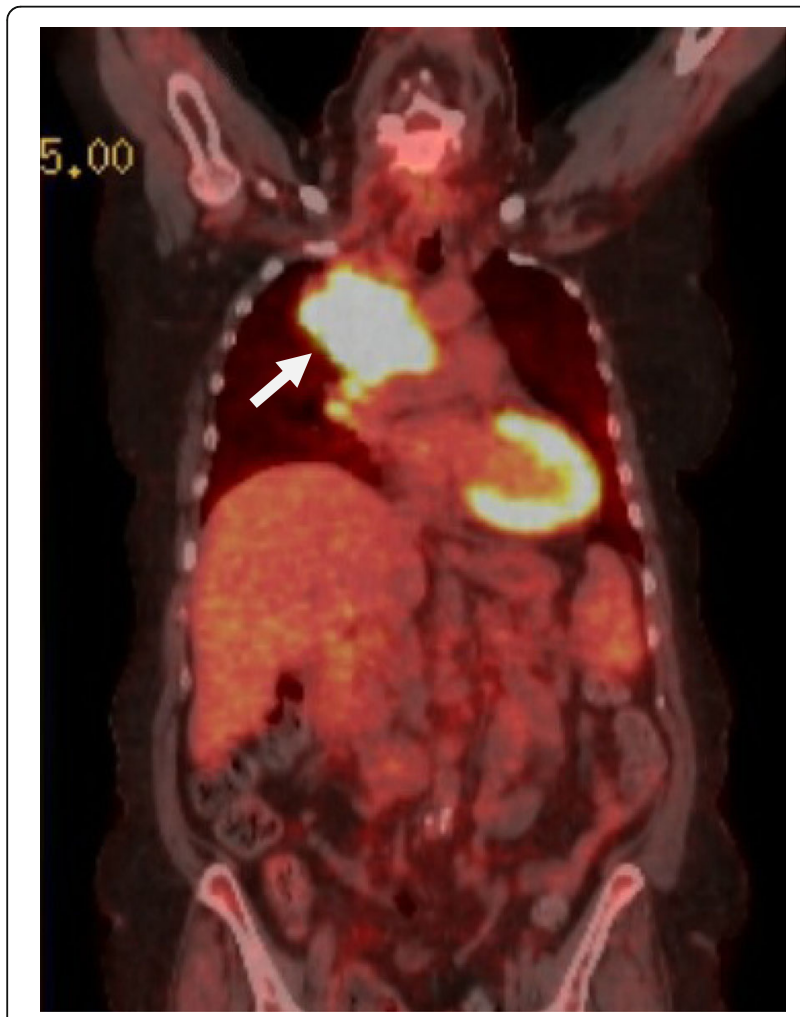

Fig. 1 Coronal PET-CT Demonstrating the Primary Lung Tumor. Legends: Coronal PET-CT indicating right upper lobular mass (white arrow) measuring $8.5 \times 5.5$ in the biaxial diameter from $8.5 \times 5.5 \mathrm{~cm}$ to $2.7 \times 0.9 \mathrm{~cm}$ with a decrease in the size of bone metastases. In addition, patient's Eastern Cooperative Oncology Group performance status (ECOG) improved from 2 prior to therapy to 0 . After week 25 of pembrolizumab, she developed Raynaud's like symptoms in both hands with mild non-purpuric erythema, pain and paresthesia at the fingertips bilaterally aggravated by cold weather. A thorough history revealed no prior autoimmune disease, recent trauma or similar symptoms in the past. The patient was started on nifedipine $30 \mathrm{mg}$ extended release orally once daily due to potential vasospasm demonstrated by the triad of pallor, cyanosis and hyperemia. There was no improvement of symptoms on 1 week follow up and nifedipine dose could not be increased due to labile blood pressure. The mild intermittent discoloration progressed to persistent periungual blue discoloration over the course of 2 weeks in the digits bilaterally. The patient was started on oral prednisone $30 \mathrm{mg}$ daily $(0.5 \mathrm{mg}$ per $\mathrm{kg}$ daily) in conjunction with nifedipine. An autoimmune panel revealed anti-nuclear antibodies (ANA) of 1:80 with a homogenous pattern; erythrocyte sedimentation rate (ESR) of $70 \mathrm{~mm} /$ hr. Further testing, including ANCA-c, ANCA-p was negative. Complement levels were within normal limits in our lab reference range. Simple nailfold capillaroscopy did not yield any abnormalities. Additional work up did not reveal a septic source, hypercoagulable disease, hyperviscosity related immunoglobulinopathies, lymphoproliferative disorders or vascular occlusion as shown in Table 1 . The patient continued on pembrolizumab given the significant interval tumor response. Over the course of 2 weeks, the patient experienced progression of the discoloration into dry gangrene, ulceration with necrosis involving all fingertips and extending to the proximal phalanges in right digits (1st' 2nd'3rd' 4th) and (1st' 2nd'3rd' 5th) digits in the left (Fig. 2). Arterial Doppler ultrasound showed normal arterial waveforms through the upper extremity arteries with peak systolic velocity ratios within normal limits. There were no signs of stenosis, atherosclerotic disease or occlusion. CT angiography showed a normal appearance of the arterial branch up to the palmar arch artery without evidence of saccular aneurysm formation, stenosis or occlusion; digital arteries were not adequately visualized. The patient underwent sympathectomy given the rapid progression of necrosis with no response to calcium channel blockers or glucocorticoids. The decision of amputation was deferred until necrotic tissue would have clear demarcation (Table 2 shows course of progression).

Pembrolizumab was stopped later (week 37) due to tumor progression and it was noted that the involved necrotic area in the digits did not progress further after discontinuation of PD-1 inhibitor. Unfortunately, the patient transferred to hospice care and expired two months after. 
Table 1 Laboratory and imaging tests performed after development of acral ischemia

\begin{tabular}{|c|c|c|}
\hline & Tests Performed & Results \\
\hline Infection & $\begin{array}{l}\text { CBC, CRP } \\
\text { Blood cultures } \\
\text { Echocardiography } \\
\text { HBV, HCV }\end{array}$ & $\begin{array}{l}\text { Normal } \\
\text { Negative } \\
\text { No vegetation or myxoma } \\
\text { Negative }\end{array}$ \\
\hline Hypercoagulable state & $\begin{array}{l}\text { Protein C } \\
\text { Protein S } \\
\text { Anti- thrombin } 3 \\
\text { Platelet } \\
\text { PT/aPTT/INT }\end{array}$ & $\begin{array}{l}131 \% \text { (Normal) } \\
73 \% \text { (Normal) } \\
\text { Normal } \\
28010 \times 3 / \text { LL (Normal) } \\
\text { Normal }\end{array}$ \\
\hline Lymphoproliferative disease & $\begin{array}{l}\text { Kappa/Lambda Ratio } \\
\text { Beta-2 microglobulin (B2M) } \\
\text { LDH } \\
\text { SPEP/IFE }\end{array}$ & $\begin{array}{l}1.37 \text { (Normal) } \\
3 \mathrm{mg} / \mathrm{L} \text { (Mildly elevated) } \\
138 \mathrm{U} / \mathrm{L} \text { (Normal) } \\
\text { Normal }\end{array}$ \\
\hline Tumor invasion & $\begin{array}{l}\text { CT Chest } \\
\text { CT Angiography }\end{array}$ & $\begin{array}{l}\text { No invasion of sympathetic nervous plexus } \\
\text { No vascular occlusion, saccular aneurysm or } \\
\text { stenosis up to the palmar arch arteries }\end{array}$ \\
\hline $\begin{array}{l}\text { Autoimmune and inflammatory disease / } \\
\text { Thromboangiitis obliterans }\end{array}$ & $\begin{array}{l}\text { ANA } \\
\text { ESR } \\
\text { CH50 } \\
\text { ANCA-c, ANCA-p } \\
\text { Cryoglobulin } \\
\text { APL ab, Anti-Scl-70 Ab, Anti-dsDNA ab, Anti-U1 RNP } \\
\text { Ab, Anti-Sm ab, Anti-Ro/SSA ab } \\
\text { Nailfold videocapillaroscopy } \\
\text { Skin biopsy }\end{array}$ & $\begin{array}{l}\text { 1:80 Homogeneous } \\
70 \mathrm{~mm} / \mathrm{hr} \\
170 \text { CAE Units (elevated) } \\
\text { (Acute phase reactant) } \\
\text { Normal } \\
\text { Negative (Normal) } \\
\text { Not performed } \\
\text { Not performed } \\
\text { Not performed }\end{array}$ \\
\hline
\end{tabular}

Ab: antibodies, APL: antiphospholipid, Anti-Scl-70: topoisomerase I, ANCA-c: Central anti-neutrophil cytoplasmic antibodies, ANCA-p: perinuclear anti- neutrophil cytoplasmic antibodies, Anti-Sm: anti smith antibodies, Anti-Ro/SSA: anti sjögren's syndrome related antigen A, SPEP: serum protein electrophoresis, IFE: immunofixation electrophoresis

\section{Discussion and conclusion}

Acral necrosis has not been documented to occur as an immune related adverse event (IRAEs) during phase I/II trials of CTLA-4 and PD-1 inhibitors [3, 4]. However, a recent French prospective multicenter study (REISA$\mathrm{MIC)}$ was conducted to assess the development of connective tissue disease after treatment with PD-1/PD-L1 inhibitors [5]. This study found the incidence to be low with only three of 447 patients who developed connective tissue disease. Interestingly, one of the three patients had small vessel vasculitis involving the digits, which was secondary to cryoglobulinemia and was associated with an elevated ANA (1:160) and anti-SSA antibodies [5]. The most common type of vasculitis that develops as an (IRAEs) involves large and medium vessels as was demonstrated in a case series by Daxini et al. [6]. This systematic review reported 20 cases of vasculitis associated with treatment with ICIs of which three were small vessel vasculitis one of them being digital ischemia [6]. There have been more cases reported in the last two years describing progression of acral necrosis, which might represent small vessel vasculitis during treatment with ICIs.

The time onset of acral ischemia developing after initiation of ICI treatment varies in the different cases reported between 3 and 26 weeks as noted in Table 3 . Similar results of previous case series have reported duration of 1.2 to 6 months before development of vasculitis after initiating treatment with ICIs [6]. Vascular risk factors such as diabetes and smoking have been reported in some patients who developed digital ischemia during treatment with ICIs. None of the patients reported in the literature had a preexisting autoimmune disease prior to initiating immunotherapy treatment. A comprehensive work up is recommended to identify the etiology of the acral ischemia which can dictate treatment strategy (Table 1 illustrates some of the tests that could help establishing a diagnosis). History and physical exam remain essential as they can guide with diagnostic work up for acral necrosis, which should consider all possible etiologies. Optimal treatment of acral necrosis in association with ICIs remains unknown given the low number of observations and multidisciplinary approach is warranted. The use of calcium channel blockers, prostaglandins and sympathectomy reported in different cases have all been unsuccessful [1, 7]. Glucocorticoids showed variable outcomes from complete resolution of the ischemia to partial or no response $[1,8]$. Rituximab was reported to be beneficial in one case and to halt the progression of acral necrosis, but the patient required digital amputation eventually [7].

We postulate two hypotheses to explain the pathophysiology for development of acral necrosis during treatment with ICIs. The first hypothesis is based on the anecdotal reports and the mechanism of action of ICIs that leads to alteration of the immunological homeostasis. This could 

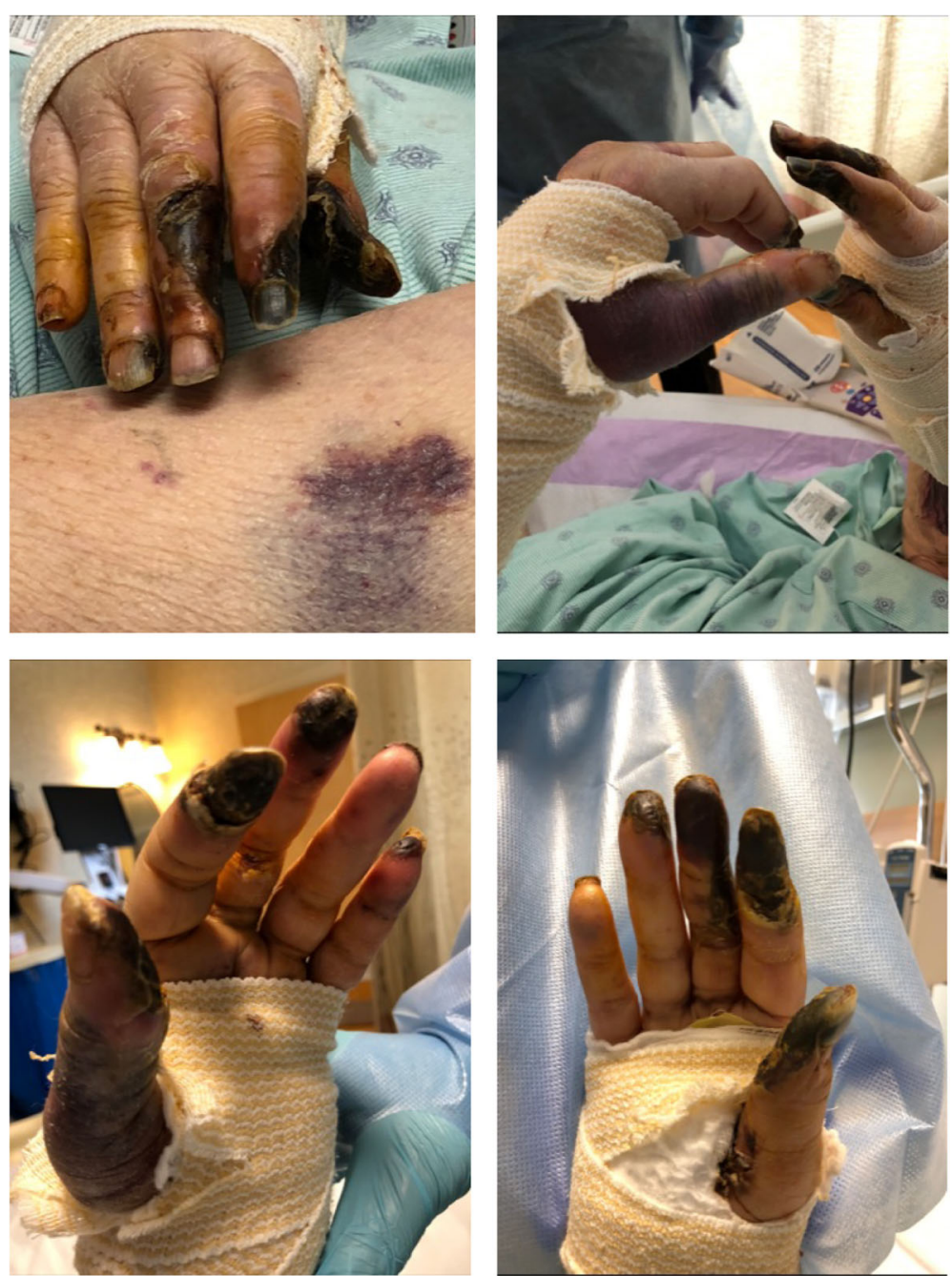

Fig. 2 Development of acral necrosis at week 33 of treatment with PD-1 inhibitors. Legends: Varying degree of extension of necrosis and ulceration involving the proximal phalanges in right (1 $\left.\mathrm{st}^{\prime} 2 \mathrm{nd}^{\prime} 3 \mathrm{rd} \mathrm{d}^{\prime} 4 \mathrm{th}\right){ }^{\text {and }}$ (1 $\mathrm{st}^{\prime} 2 \mathrm{nd} \mathrm{d}^{\prime} 3 \mathrm{rd} \mathrm{d}^{\prime} 5 \mathrm{th}$ ) digits in the left hand. There is no presence of calcinosis or involvement of the bone protuberants

Table 2 Timeline of progression of acral necrosis since administration of PD-1 inhibitor

\begin{tabular}{|c|c|}
\hline $\begin{array}{l}\text { Timeline from } \\
\text { Treatment }\end{array}$ & Clinical Progression \\
\hline Day 0 & 1st dose of pembrolizumab (No symptoms) \\
\hline At 25 weeks & $\begin{array}{l}\text { Raynaud's like symptoms (Patient started on } \\
\text { nifedipine) }\end{array}$ \\
\hline At 27 weeks & $\begin{array}{l}\text { No resolution of Raynaud's symptoms and } \\
\text { persistence of cyanosis (Patient started on } \\
\text { prednisone) }\end{array}$ \\
\hline At 29 weeks & $\begin{array}{l}\text { Development of dry gangrene at fingertips } \\
\text { bilaterally }\end{array}$ \\
\hline At 33 weeks & $\begin{array}{l}\text { Extension of necrosis and development of } \\
\text { ulceration. Patient still on pembrolizumab. } \\
\text { Sympathectomy performed (patient still on } \\
\text { nifedipine and glucocorticoids) }\end{array}$ \\
\hline At 37 weeks & $\begin{array}{l}\text { Tumor progression (pembrolizumab stopped). } \\
\text { Extension of the necrosis stopped after week } 37\end{array}$ \\
\hline
\end{tabular}

lead to either activation of $\mathrm{T}$ cell population or antibody formation against self-antigens (endothelial cells in this case) which theoretically could cause vasculitis related syndromes. Zhang et al. examined the role of PD-1/PD-L1 inhibition on the development of vasculitis specifically giant cell arteritis and concluded that blockade of the coninhibitory ligand can initiate $\mathrm{T}$ cell infiltration of the vascular endothelium and exacerbate an inflammatory response that leads to vasculitis [9]. However, Zhang's study involved giant cell arteritis, which is a medium/ large vessel vasculitis. Moreover, PD-1 receptor impairment has been described to induce autoantibodies against shared antigens between the tumor and normal tissue knock-out mice models leading to lupus-like syndrome [10]. Some literature regarding digital ischemia favors autoimmune involvement during treatment with ICIs. As an example, Comont et al. described a case of acral 
Table 3 Summary of case reports of digital ischemia and small vessel vasculitis with immune-check point inhibitors use

\begin{tabular}{|c|c|c|c|c|c|c|c|c|}
\hline Case & $\begin{array}{l}\text { Age } \\
\text { /Gender }\end{array}$ & $\begin{array}{l}\text { Vascular } \\
\text { Risk } \\
\text { Factors }\end{array}$ & Malignancy & Medication & Symptoms & $\begin{array}{l}\text { Duration } \\
\text { before } \\
\text { onset of } \\
\text { symptoms }\end{array}$ & Treatment & $\begin{array}{l}\text { Final } \\
\text { Outcome }\end{array}$ \\
\hline $\begin{array}{l}\text { Gambichler } \\
\text { et al. [1] }\end{array}$ & $\begin{array}{l}60 / \\
\text { Male }\end{array}$ & None & $\begin{array}{l}\text { Metastatic } \\
\text { Melanoma } \\
\text { BRAF } \\
\text { V600E } \\
\text { Mutated }\end{array}$ & $\begin{array}{l}\text { Ipilimumab + } \\
\text { Nivolumab }\end{array}$ & $\begin{array}{l}\text { Subungal necrosis followed } \\
\text { by gangrene }\end{array}$ & 3 weeks & $\begin{array}{l}\text { Prostacycline, } \\
\text { methylprednisolone (50 } \\
\text { mg in tapering dose), } \\
\text { methylprednisolone } 500 \\
\text { mg }\end{array}$ & $\begin{array}{l}\text { Surgical } \\
\text { amputation }\end{array}$ \\
\hline $\begin{array}{l}\text { Padda et al. } \\
{[7]}\end{array}$ & $\begin{array}{l}52 / \\
\text { Female }\end{array}$ & None & $\begin{array}{l}\text { Metastatic } \\
\text { Melanoma }\end{array}$ & Ipilimumab & Digital Necrosis & 3 weeks & $\begin{array}{l}\text { Amlodipine, Aspirin, } \\
\text { Prednisone ( } 60 \text { mg), } \\
\text { methyl prednisolone } 500 \\
\text { mg, epoprostenol, Normal } \\
\text { Saline, Rituximab }\end{array}$ & $\begin{array}{l}\text { Surgical } \\
\text { amputation }\end{array}$ \\
\hline $\begin{array}{l}\text { Thoreau et } \\
\text { al. [12] }\end{array}$ & $\begin{array}{l}73 / \\
\text { Male }\end{array}$ & Diabetes & $\begin{array}{l}\text { Metastatic } \\
\text { Melanoma }\end{array}$ & Pembrolizumab & $\begin{array}{l}\text { Acute ischemia of the left } \\
\text { toes }\end{array}$ & 26 weeks & $\begin{array}{l}\text { lloprost, anticoagulation, } \\
\text { amputation, aspirin, } \\
\text { fogarty arterial } \\
\text { embolectomy }\end{array}$ & $\begin{array}{l}\text { Surgical } \\
\text { amputation }\end{array}$ \\
\hline $\begin{array}{l}\text { Comont et } \\
\text { al. [8] }\end{array}$ & $\begin{array}{l}66 / \\
\text { Male }\end{array}$ & Smoker & $\begin{array}{l}\text { Urothelial } \\
\text { Bladder } \\
\text { Cancer }\end{array}$ & $\begin{array}{l}\text { Tremelimumab } \\
+ \text { durvalumab/ } \\
\text { Chemotherapy }^{\mathrm{a}}\end{array}$ & $\begin{array}{l}\text { Periungal skin necrosis } \\
\text { bilaterally }\end{array}$ & 20 weeks & $\begin{array}{l}\text { Prednisone } 1 \mathrm{mg} / \mathrm{kg} \\
\text { Immunotherapy } \\
\text { discontinuation }\end{array}$ & $\begin{array}{l}\text { Complete } \\
\text { resolution }\end{array}$ \\
\hline $\begin{array}{l}\text { Leburel et } \\
\text { al. [5] }\end{array}$ & 60/Male & $\begin{array}{l}\text { Not } \\
\text { available }\end{array}$ & Melanoma & $\begin{array}{l}\text { PD-L1 inhibitor } \\
+ \text { BRAF and } \\
\text { MEK inhibitors }\end{array}$ & $\begin{array}{l}\text { Cyanosis of fingers, necrosis } \\
\text { of } 3 \text { fingers and the heels, } \\
\text { arthralgia, dry mouth, } \\
\text { paresthesia of feet and } \\
\text { interstitial pneumonia }\end{array}$ & 8.5 weeks & $\begin{array}{l}\mathrm{ICl} \text { withdrawal, prednisone } \\
1 \mathrm{mg} / \mathrm{kg}, \mathrm{CCB} \text {, iloprost and } \\
\text { ASA }\end{array}$ & $\begin{array}{l}\text { Partial } \\
\text { resolution }\end{array}$ \\
\hline
\end{tabular}

${ }^{a}$ Methotrexate, vinblastine, doxorubicin and cisplatin

ASA acetylsalicylic acid, CCB calcium channel blockers

necrosis during combined treatment with CTLA-4 and PD-L1 inhibitors that was associated with increased titers of ANA (1:5200) which would support an autoimmune etiology [8]. In this case, there was a complete reversal of the acral ischemia with high suppressive dose of prednisone $(1 \mathrm{mg} / \mathrm{kg}$ daily) [8]. However, the patient of the previous study received chemotherapy prior to ICI includeding methotrexate, vinblastine, doxorubicin and cisplatin which could be culprits in acral necrosis. Similarly, a patient who developed digital ischemia in (REISAMIC) study had high ANA titers (160, speckled pattern) and responded well to steroids with partial resolution of ischemic symptoms [5]. In our patient, there was a weak evidence of an autoimmune process due to borderline ANA and elevated ESR which were nonspecific for a definitive diagnosis for autoimmune conditions as they can be elevated in various non-immunologic conditions and our patient did not have a good response to prednisone (received prednisone0.5 $\mathrm{mg} / \mathrm{kg} /$ day). In addition, Gambichler et al. performed a tissue biopsy from the area of acral necrosis in their patient, which did not reveal any evidence of $\mathrm{T}$ cell infiltration or immune complex precipitation that might represent leuococytoclastic vasculitis [1].

The second hypothesis for the development of acral necrosis with ICIs treatment is the proinflammatory effect causing vascular damage. The endothelial insult could induce either atherosclerotic lesions or a procoagulable state, which might lead to vascular (arterial) thrombosis. Mice models that lacked PD-1 receptors due to PD-1 blockade had more abundant T cell inflammatory infiltrate in atherosclerotic lesions compared to control mice models suggesting that PD-1 impairment can lead to proatherogenic state [11]. In our search of the literature there was one case that involved acral ischemia of left toes with the use of PD-1 inhibitors. The patient was later found to have arterial thrombosis, which was removed with fogarty thrombectomy and was believed to be secondary to PD-1 inhibitor. However, the patient had diabetes mellitus with diabetic ketoacidosis, which also could induce endothelial inflammatory damage under oxidative stress leading to arterial thrombosis [12].

Historically, the observed phenomenon of acral ischemia was described early in the literature in association with malignancy and was considered a manifestation of a paraneoplastic syndrome [13]. The pathophysiology of paraneoplastic acral vascular syndrome (PAVS) is not well established. Many cases described development of acral ischemia with specific chemotherapies including gemcitabine and carboplatin leading to think that medication could be a culprit in the development of acral ischemia [14, 15]. Older generation immunotherapies like interferon may potentially cause acral ischemia as noted in a case series by Sharpai et al. which identified Raynaud's like syndrome and acral arterial occlusion in 12 patients of 24 who were treated with interferon [16]. 
Other studies have emphasized these findings and have showed interferon alpha/beta to cause endothelial injury in the microvasculature leading to impaired subcutaneous tumor blood flow in mice models [17]. Paraneoplastic acral vascular necrosis is more frequently encountered in association with adenocarcinoma followed by squamous cell carcinoma and hematologic malignancies from a cohort of 100 patients who were hospitalized due to digital ischemia [18]. This study found an incidence of $15 \%$ of malignancy associated with digital ischemia [18].

To our knowledge, our report is the first to describe development of acral necrosis with the use of pembrolizumab, which is a humanized monoclonal antibody against programmed death 1 receptors [19].

Acral vascular necrosis can develop in association with malignancies and during treatment. It is controversial whether this complication represents an immune related adverse event to the use of ICIs. Physicians should have a high index of suspicion when Raynaud's like symptoms occur during treatment of malignancy and monitor closely for development of digital ischemia and necrosis. Larger studies are needed to identify the etiology of this complication.

\section{Abbreviations \\ ANA: Antinuclear antibodies; CTLA-4: Cytotoxic T lymphocyte antigen-4; ICls: Immune-check point inhibitors; IRAEs: Immune related adverse events; PAVS: Paraneoplastic acral vascular syndrome; PD-1/PD-L1: Programmed death-1/ programmed death- ligand 1}

\section{Acknowledgements}

The authors would like to thank Dr. Preston B Cannady for reviewing of the manuscript.

\section{Funding}

No sources of funding were utilized in the preparation of this report.

\section{Availability of data and materials}

All data generated or analyzed during this case study are included in this published article.

\section{Authors' contributions \\ KK "corresponding author" contributed to the production of the case report, conceptualization of the discussion along with literature review and providing the images and tables. VS and MS contributed to reviewing the manuscript production. All authors have read and approved the manuscript.}

\section{Ethics approval and consent to participate}

Not applicable.

\section{Consent for publication}

Written informed consent for publication of the clinical details and clinical images was obtained from the patient's medical power of attorney. A copy of the written consent is available for review by the editor of the journal.

\section{Competing interests}

The authors declare that they have no competing interests.

\section{Publisher's Note}

Springer Nature remains neutral with regard to jurisdictional claims in published maps and institutional affiliations.

\section{Author details}

'Rosalind Franklin University of Medicine and Science, 915 Armistead Lane, McHenry, Chicago, IL 60050, USA. ${ }^{2}$ North Western Medicine Centegra Healthcare System, Chicago, USA.

Received: 3 December 2018 Accepted: 30 April 2019

Published online: 14 May 2019

\section{References}

1. Gambichler T, et al. Paraneoplastic acral vascular syndrome in a patient with metastatic melanoma under immune checkpoint blockade. BMC Cancer. 2017;17:327

2. Reck M, et al. Pembrolizumab versus chemotherapy for PD-L1-positive nonsmall-cell lung Cancer. N Engl J Med. 2016 Nov 10;375(19):1823-33.

3. Brahmer JR, Tykodi SS, Chow LOM, Hwu W-J, et al. Safety and activity of anti-PD-L1 antibody in patients with advanced cancer. N Engl J Med. 2012;366:2455-65.

4. Wolchok JD, Neyns B, Linette G, et al. Ipilimumab monotherapy in patients with pretreated advanced melanoma: a randomised, double-blind, multicentre, phase 2, dose-ranging study. Lancet Oncol. 2010;11:155-64.

5. Le Burel S, Champiat S, Routier E, Aspeslagh $\mathrm{S}$, et al. Onset of connective tissue disease following anti-PD1/PD-L1 cancer immunotherapy. Ann Rheum Dis. 2018:77:468-70.

6. Daxini A, Cronin K, Sreih AG. Vasculitits associated with immune checkpoint inhibitors-a systematic review. Clin Rheumatol. 2018;37:2579-84.

7. Padda A, et al. Ipilimumab induced digital vasculitis. J Immunother Cancer. 2018:6:12.

8. Comont T, Sibaud V, Mourey L, Cougoul P, Beyne-Rauzy O. Immune checkpoint inhibitor-related acral vasculitis. J Immunother Cancer. 2018;16(6):120

9. Zhang $\mathrm{H}$, et al. Immunoinhibitory checkpoint deficiency in medium and large vessel vasculitis. Proc Natl Acad Sci U S A. 2017 Feb 7;114(6):E970-9.

10. Okazaki T, et al. Autoantibodies against cardiac troponin I are responsible for dilated cardiomyopathy in PD-1-deficient mice. Nat Med. 2003:9:1477-83.

11. Bu D, Tarrio M, Maganto-Garcia E, Stavrakis G, Tajima G, Lederer J, et al. Impairment of the programmed cell death-1 pathway increases atherosclerotic lesion development and inflammation. Arterioscler Thromb Vasc Biol. 2011 May:31(5):1100-7.

12. Thoreau B, Gouaillier-Vulcain F, Machet L, et al. Acute lower limb Ischaemia and diabetes in a patient treated with anti-PD1 monoclonal antibody for metastatic melanoma. Acta Derm Venereol. 2017;10(97):408-9.

13. Hawley PR, Johnston AW, Rankin JT. Association between digital ischaemia. Br Med J. 1967:3:208-12.

14. Dasanu CA. Gemcitabine: vascular toxicity and prothrombotic potential. Expert Opin Drug Saf. 2008;7:703-16.

15. Staff S, Lagerstedt E, Seppänen J, et al. Acute digital ischemia complicating gemcitabine and carboplatin combination chemotherapy for ovarian cancer. Acta Obstet Gynecol Scand. 2011;90:1296-7.

16. Schapira D, Nahir AM, Hadad N. Interferon-induced Raynaud's syndrome. Semin Arthritis Rheum. 2002;32:157-62.

17. Dvorak HF, Gresser I. Microvascular injury in pathogenesis of interferoninduced necrosis of subcutaneous tumors in mice. J Natl Cancer Inst. 1989; 5(81):497-502.

18. Le Besnerais M, Miranda S, et al. Digital Ischemia Associated with Cancer Results from a Cohort Study. Medicine (Baltimore). 2014;93:e47.

19. Fessas P, et al. A molecular and preclinical comparison of the PD-1-targeted T-cell checkpoint inhibitors nivolumab and pembrolizumab. Semin Oncol. 2017:44:136-40

Ready to submit your research? Choose BMC and benefit from

- fast, convenient online submission

- thorough peer review by experienced researchers in your field

- rapid publication on acceptance

- support for research data, including large and complex data types

- gold Open Access which fosters wider collaboration and increased citations

- maximum visibility for your research: over $100 \mathrm{M}$ website views per year

At $B M C$, research is always in progress.

Learn more biomedcentral.com/submissions 